\title{
PENGARUH NILAI PELANGGAN DAN KUALITAS PELAYANAN TERHADAP LOYALITASNASABAH PADA KSP (CU) MAJU BERSAMA KASIKAN, TAPUNG HULU, KABUPATEN KAMPAR, RIAU
}

\author{
ANITHA PAULINA TINAMBUNAN ${ }^{1}$ \\ MARIANI SELVIA SIBURIAN ${ }^{2}$ \\ Fakultas Ekonomi Universitas Katolik Santo Thomas \\ anithapaulinat@gmail.com
}

\begin{abstract}
ABSTRAK
Penelitian ini bertujuan untuk mengetahui apakah ada pengaruh antara customer value dan kualitas layanan terhadap loyalitas pelanggan baik secara parsial maupun serentak pada KSP (CU) Maju Bersama Kasikan, Tapung Hulu, Kabupaten Kampar, Riau. Populasi penelitian ini adalah pengguna jasa KSP (CU) Maju Bersama Kasikan, Tapung Hulu, Kabupaten Kampar, Riau dengan total sampel 97 responden. Metode pengumpulan data dengan kuesioner. Teknik analisis data yang digunakan adalah regresi linier berganda. Persamaan regresi linier berganda yang diperoleh dari hasil tes adalah $\mathrm{Y}=9.708+0.223(\mathrm{X} 1)+0,119(\mathrm{X} 2)+$ ei, yang berarti bahwa nilai pelanggan simultan dan kualitas layanan memiliki efek positif dan signifikan terhadap loyalitas pelanggan pengguna jasa KSP (CU) Maju Bersama K, Tapung Hulu, Kabupaten Kampar, Riau. Namun, variabel nilai pelanggan adalah variabel yang paling tidak terpengaruh pada loyalitas pelanggan pengguna jasa KSP (CU) Maju Bersama Kasikan, Tapung Hulu, Kabupaten Kampar, Riau. R square sebesar 0.782, yang berarti bahwa variasi loyalitas pelanggan dapat dijelaskan oleh nilai pelanggan dan kualitas layanan sebesar $78,2 \%$ dan $21,8 \%$ sisanya dapat dijelaskan oleh variabel lain yang tidak dijelaskan dalam penelitian ini. Dari hasil penelitian dan diskusi, KSP (CU) Maju Bersama Kasikan, Tapung Hulu, Kabupaten Kampar, Riau harus lebih mengembangkan dan menjaga nilai pelanggan serta kualitas layanan, sehingga karyawan dapat meningkatkan loyalitas pelanggan.
\end{abstract}

Kata Kunci : Nilai Pelanggan, Kualitas Pelayanan, Loyalitas Pelanggan

\section{PENDAHULUAN}

Salah satu tantangan terbesar dalam bisnis adalah menciptakan dan mempertahankan loyalitas pelanggan/nasabah. Pelanggan membentuk suatu harapan akan nilai dan bertindak berdasarkan hal itu. Nilai pelanggan sebagai prefensi perseptual dan evaluasi pelanggan terhadap atribut produk, dan konsekuensi yang didapatkan dari pemakaian produk jasa yang memfasilitasi pencapaian tujuan dan sasaran konsumen dalam situasi pemakaian Tingkat persepsi tentang kualitas layanan (nilai) yang tinggi akan menghasilkan kepuasan pelanggan. Pemasar dapat meningkatkan penawaran dengan menaikkan kombinasi manfaat, fungsional, psikis maupun emosional, sementara pelanggan mendapat manfaat dari mengendalikan sepenuhnya biaya yang akan dikeluarkan.

Asset yang sangat bernilai bagi organisasi adalah loyalitas pelanggan/nasabah. Pelanggan/nasabah dikatakan loyal pada merk atau perusahaan tertentu apabila pelanggan tersebut konsisten melakukan pembelian ulang terhadap merk tertentu pada perusahaan yang sama, menceritakan dan memberikan rekomendasi kepada orang lain, tidak terpengaruh dengan tawaran harga yang menarik dari perusahaan saingan dan menyampaikan komplain kepada perusahaan dengan cara baik dan sesuai prosedur. Jika perusahaan kehilangan banyak pelanggan/nasabah maka perusahaan akan mengalami kerugian karena harus mengeluarkan biaya untuk menarik pelanggan baru dan membutuhkan waktu lama untuk menjadikannya nasabah yang loyal.

Banyak faktor yang mempengaruhi loyalitas pelanggan/nasabah, diantaranya yaitu kualitas pelayanan dan nilai pelanggan. Dick dan Basu mengatakan loyalitas nasabah sebagai komitmen nasabah terhadap suatu merek dan pemasok, berdasarkan sikap yang positif dan tercermin dalam pembelian ulang yang konsisten. Umar (2003). Sheth dan Mittal (2004) merumuskan definisi loyalitas nasabah dengan menggabungkan unsur sikap dan perilaku pembelian sebagai berikut : Nasabah dikatakan loyal jika memiliki sikap positif terhadap merek tertentu dan dimanifestasikan dalam bentuk pembelian ulang secara konsisten.Nasabah dikatakan loyal pada merk atau perusahaan tertentu jika 
konsisten melakukan pembelian ulang, menceritakan dan memberikan rekomendasi kepada orang lain, tidak terpengaruh dengan tawaran harga yang menarik dari perusahaan saingan dan menyampaikan komplain kepada perusahaan dengan cara baik dan sesuai prosedur.

Pelanggan membentuk suatu harapan akan nilai dan bertindak berdasarkan hal itu. Nilai pelanggan merupakan persepsi konsumen terhadap nilai atas kualitas barang/jasa yang ditawarkan peusahaan. Tingkat persepsi tentang kualitas layanan (nilai) yang tinggi akan menghasilkan kepuasan pelanggan. Semakin tinggi persepsi nilai yang dirasakan oleh pelanggan, maka semakin besar kemungkinan terjadinya hubungan (transaksi). Nilai pelanggan secara positif dan signifikan mempengaruhi minat pelanggan untuk mereferensikan produk perusahaan, misalnya kepada teman, atasan dan orang yang dikenal. Semakin tinggi derajat nilai pelanggan yang dihasilkan, maka semakin tinggi minat pelanggan untuk mereferensikan produk perusahaan kepada pihak-pihak lain. Semakin tinggi nilai pelanggan terhadap perusahaan maka nasabah akan semakin loyal dengan perusahaan. Hal ini sejalan dengan penelitian yang dilakukan oleh Fergiawan (2016) yang menyatakan bahwa nilai pelanggan berpengaruh positif dan signifikan terhadap loyalitas nasabah.

Kualitas pelayanan adalah kunci keberhasilan dalam berbagai usaha yang bersifat jasa. .Kualitas pelayanan tidak dapat dinilai berdasarkan sudut pandang perusahaan tetapi harus dipandang dari sudut penilaian pelanggan.Karena itu, dalam merumuskan strategi dan program pelayanan, perusahaan harus berorientasi kepada kepentingan pelanggan dengan memperhatikan komponen kualitas pelayanan. Kualitas pelayanan adalah predictor penting loyalitas nasabah. Kualitas pelayanan yang bertaraf tinggi akan menghasilkan kepuasan yang tinggi bagi nasabah dan menarik orang lain untuk menjadi nasabah baru dan membantu perusahaan untuk meningkatkan eksistensinya ditengah masyarakat Kotler (2002).Semakin baik kualitas layanan maka akan semakin tinggi loyalitas nasabah. Jika pelayanan yang diberikan berkualitas, maka nasabah akan merasa puas dan loyalitas nasabah terhadap perusahaan meningkat. Hal ini sejalan dengan hasil penelitian Akbar dan Parves (2009) yang mengatakan terdapat hubungan yang positif dan signifikan antara kualitas pelayanan terhadap loyalitas nasabah. nasabah:

Penelitian yang berkaitan dengan variabel kualitas pelayanan, nilai pelanggan dan kepuasan

1. Dani (2016) melakukan penelitian dengan judul "Pengaruh Kualitas Pelayanan, Nilai Nasabah dan Kepuasan Nasabah Terhadap Loyalitas Nasabah Tami Umum PT BPR Batang Selo Nagari Padang Ganting Kab. Tanah Datar“. Hasil penelitiannya menyimpulkan bahwa kualitas pelayanan dan nilai pelanggan berpengaruh positif dan signifikan terhadap loyalitas nasabah.

2. Penelitian Richi Irawan (2015) dengan judul "Pengaruh Kualitas Pelayanan dan Nilai Pelanggan Terhadap Loyalitas Nasabah Bank BRI KK Unisma Malang”. menyimpulkan bahwa kualitas pelayanan dan nilai pelanggan berpengaruh positif dan signifikan terhadap loyalitas nasabah.

KSP (CU) Maju Bersama adalah koperasi kredit/credit union yang berkantor pusat di KompleksGereja Katolik, Jl. Raya Suram-Kasikan, Desa Kasikan, Kec. Tapung Hulu, Kab. Kampar, Riau. Berdasarkan hasil penelitian diketahui tingkat kualitas pelayanan pada KSP (CU) Maju Bersama Kasikan, Tapung Hulu, Kabupaten Kampar, Riau masih rendah.

Tabel 1. Data Nasabah pada KSP (CU) Maju Bersama Kasikan, Tapung Hulu, KabupatenKampar, Riau (Tahun 2016 - 2018)

\begin{tabular}{|c|l|c|c|c|}
\hline Tahun & $\begin{array}{l}\text { Jumlah Nasabah } \\
\text { (Orang) }\end{array}$ & Out (Keluar) & In (Masuk) & $\begin{array}{l}\text { Nasabah yangkeluar } \\
(\%)\end{array}$ \\
\hline 2016 & 9.737 & 328 & 2.184 & 30 \\
\hline 2017 & 10.468 & 706 & 1.492 & 14,82 \\
\hline 2018 & 10.906 & 601 & 1.112 & 18,14 \\
\hline
\end{tabular}

Sumber : KSP (CU) Maju Bersama Tahun 2019

Data pada tabel 1 di atas mengindikasikan loyalitas nasabah KSP (CU) Maju Bersama Kasikan, Tapung Hulu, Kabupaten Kampar, Riau mengalami fluktuasi. Meskipun ada nasabah yang bertambah, namun jumlah nasabah yang keluar cukup banyak, bahkan sampai 30\% pada tahun 2016. Hal ini 
disebabkan karena kualitas pelayanan yang diberikan belum sesuai dengan harapan nasabah. Proses rekap transaksi berjalan lamban dan nasabah harus lama berdiri untuk mengantri karena kurangnya fasilitas tempat duduk.

\section{TINJAUAN PUSTAKA DAN HIPOTESIS}

Jasa adalah pemberian suatu kinerja atau tindakan tak kasat mata dari satu pihak kepada pihak lain. Dalam pengertian yang lain, jasa adalah kegiatan yang dapat diidentifikasikan, yang bersifat tak teraba, yang direncanakan untuk pemenuhan kepuasan konsumen. Pada umumnya jasa diproduksi dan dikonsumsi secara bersamaan, di mana interaksi antara pemberi jasa dan penerima jasa mempengaruhi hasil jasa tersebut.. Menurut Kotler (2012) karakteristik pemasaran jasa ada 4 yaitu :

a. Intangibility (Tidak Berwujud). Jasa tidak dapat dilihat, dirasa, diraba, didengarkan atau dicium sebelum jasa itu dibeli.

b. Perishability (Tidak Tahan Lama).Jasa merupakan komoditas tidak tahan lama dan tidak dapat disimpan.Daya tahan suatu jasa tergantung suatu situasi yang diciptakan oleh berbagai faktor.

c. Inseparability (Tidak Terpisahkan). Karakteristik jasa ini berarti jasa dihasilkan dan dikonsumsi secara bersamaan.

d. Variability (Bervariasi). Jasa sangat bervariasi bergantung pada siapa yang memberikannya, kapan dan dimana diberikan.

Karakteristik yang dimiliki oleh jasa memiliki esensi utama yaitu perlunya keterlibatan secara langsung karyawan dalam proses pengiriman, sehingga menjadi ujung tombak keberhasilan jasa. Tetapi dengan perkembangan teknologi, ketergantungan terhadap karyawan dapat dieliminasi dan kontak pelanggan langsung yang sangat mahal dapat dikurangi. Pemasaran merupakan landasan utama dalam bisnis dan masyarakat. Bauran pemasaran mempengaruhi minat konsumen dalam melakukan keputusan pembelian.Bauran pemasaran jasa dikenal dengan istilah $7 \mathrm{P}$ yang terdiri dari Kotler dan Amstrong, (2008).

1. Product (Produk)

Mengelola unsur produk termasuk perencanaan dan pengembangan produk atau jasa yang tepat untuk dipasarkan dengan mengubah produk atau jasa yang ada dengan menambah dan mengambil tindakan yang lain yang mempengaruhi bermacam-macam produk atau jasa.

2. Price (Harga)

Suatu sistem manajemen perusahaan yang akan menentukan harga dasar yang tepat bagi produk atau jasa dan harus menentukan strategi yang menyangkut potongan harga, pembayaran ongkos angkut dan berbagi variabel yang bersangkutan.

3. Place (Tempat)

Memilih dan mengelola saluran perdagangan yang dipakai untuk menyalurkan produk atau jasa dan juga untuk melayani pasar sasaran, serta mengembangkan sistem distribusi untuk pengiriman dan perniagaan produk secara fisik.

4. Promotion (Promosi)

Unsur yang digunakan untuk memberitahukan dan membujuk pasar tentang produk atau jasa yang baru pada perusahaan melalui iklan, penjualan pribadi, promosi penjualan, maupun publikasi.

5. Physical Evidence (Fasilitas Fisik)

Sarana fisik turut mempengaruhi keputusan konsumen untuk membeli dan menggunakan produk atau jasa yang ditawarkan. Unsur yang termasuk dalam sarana fisik antara lain lingkungan atau bangunan fisik, peralatan, perlengkapan, logo, warna dan barang-barang lainnya.

6. People (Orang)

Semua pelaku yang memainkan peranan penting dalam penyajian jasa sehingga dapat mempengaruhi persepsi pembeli. Sikap, tindakan, penampilan dan cara berpakaian karyawan memiliki pengaruh terhadap keberhasilan penyampaian jasa.

7. Process (Proses)

Proses dalam jasa merupakan faktor utama dalam bauran pemasaran jasa seperti pelanggan jasa akan senang merasakan sistem penyerahan jasa sebagai bagian jasa itu sendiri.

\section{Nilai Pelanggan (Customer Value)}

Nilai pelanggan merupakan keseluruhan penilaian konsumen terhadap suatu produk berdasarkan 
persepsinya tentang serangkain manfaat yang didapatkan dari seberapa besar yang dikorbankan untuk mendapatkan produk. Buchari (2007) menyatakan nilai pelanggan ialah selisih antara total nilai tambah yang diperoleh konsumen dibandingkan dengan total biaya yang dikeluarkan. Nilai Pelanggan yang diwakili oleh total produk atau jasa yang kemudian dilempar ke pasar sasaran untuk kemudian pasar sasaran tersebut melakukan proses pengambilan keputusan berdasarkan persepsi mereka terhadap nilai yang dirasakan. Zeithalm (2003) menyatakan ada empat faktor yang mempengaruhi nilai pelanggan yaitu:

a. Apa yang didengar pelanggan dari pelanggan lainnya. Dimana hal ini merupakan faktor potensial yang menentukan ekspektasi pelanggan.

b. Ekspektasi pelanggan sangat bergantung dari karakteristik individu dimana kebutuhan pribadi.

c. Pengalaman masa lalu dalam menggunakan pelayanan dapat juga mempengaruhi nilai pelanggan.

d. Komunikasi dengan pihak eksternal dari pemberi layanan memainkan peranan kunci dalam membentuk ekspektasi.

Nilai pelanggan sebagai prefensi perseptual dan evaluasi pelanggan terhadap atribut produk, dan konsekuensi yang didapatkan dari pemakaian produk dan jasa yang memfasilitasi pencapaian tujuan dan sasaran konsumen dalam situasi pemakaian.Menurut Sweeney dan Soutar (2001) ada beberapa indikator yang membentuk nilai pelanggan yaitu:

1. Nilai Emosional (Emotional Value)

Nilai emosional merupakan nilai yang berasal dari kemampuan produk untuk menimbulkan perasaan positif pada diri konsumen. Atribut dari nilai emosional meliputi kemampuan sebuahproduk untuk menimbulkan rasa ingin mengkonsumsi produk tersebut dan kemampuan sebuah produk untuk menciptakan rasa senang atau puas pada konsumen. Nilai emosional akan mempengaruhi kepuasan konsumen karena berkaitan dengan kemampuan produk menciptakan rasa senang bagi penggunanya. Semakin tinggi nilai emosional yang terbentuk maka akan semakin tinggipula kepuasan konsumen.

2. Nilai Sosial (Social Value)

Nilai sosial merupakan nilai yang didapatkan dari kemampuan produk untuk meningkatkan konsep diri sosial konsumen. Atribut dari nilai sosial tersebut meliputi kemampuan sebuah produk untuk menimbulkan rasa bangga kepada konsumen dan kemampuan sebuah produk untuk menimbulkan kesan yang baik kepada konsumen. Nilai sosial mempunyai pengaruh positif terhadap kepuasan konsumen karena berkaitan dengan kemampuan sebuah produk atau jasa untuk meningkatkan konsep diri sosial konsumen. Semakin tinggi penilaian konsumen dari segi sosial terhadap sebuah produk atau jasa maka akan semakin tinggi pula kepuasan yang terbentuk.

3. Nilai Kualitas (QualityValue)

Nilai kualitas merupakan nilai yang diperoleh dari persepsi pelanggan terhadap kualitas dan kinerja yang diharapkan atas produk atau jasa. Atribut dari nilai kualitas meliputi manfaat yang diperoleh konsumen setelah mengkonsumsi produk tersebut dan konsistensi pelayanan oleh karyawan perusahaan. Nilai kualitas memberikan kontribusi yang besar terhadap terbentuknya kepuasan konsumen. Semakin tinggi penilaian konsumen terhadap kualitas dan kinerja atas sebuah produk atau jasa maka akan semakin tinggi pula tingkat kepuasan konsumen.

4. $\quad$ Nilai Terhadap Biaya (Price Value For Money)

Nilai terhadap biaya merupakan nilai yang didapatkan dari produk karena redukasi biaya jangka panjang. Atribut dari nilai terhadap biaya meliputi perbandingan biaya yang dikeluarkan dengan manfaat yang diperoleh dari produk tersebut dan perbandingan biaya yang dikeluarkan untuk produk tersebut dengan produk serupa dari perusahaan lain. Nilai ini akan sangat berpengaruh terhadap kepuasan konsumen karena konsumen akan membandingkan harga dengan manfaat yang diperoleh dari produk tersebut. Harga yang tidak terlalu tinggi dan masuk akal dengan manfaat lebih yang diperoleh dari sebuah produk maka akan terbentuk kepuasan konsumen, begitu juga sebaliknya.

Menurut Sheth dan Mittal ada beberapa indikator nilai pelanggan yaitu: Setiawan(2012)

- $\quad$ Performance Value (Nilai Kinerja)

Kualitas hasil fisik dari pengguna suatu produk dan jasa. Dengan kata lain, tipe nilai ini 
mencerminkan kemampuan produk atau jasa melaksanakan fungsi fisik secara konsisten.

- $\quad$ Credit Value (Nilai Kredit)

Berupa situasi terbebas dari keseharusan membayar kas pada saat pembelian atau membayar dalam waktu dekat.Pada prinsipnya, nilai ini menawarkan kenyamanan berkenan dengan pembayaran.

- $\quad$ Service Value (Nilai Pelayanan)

Berupa bantuan yang diharapkan pelanggan berkaitan pembelian produk atau jasa.

- $\quad$ Convenience Value (Nilai Kenyamanan)

Berupa penghemat waktu dan usaha yang dibutuhkan untuk memperoleh produk atau jasa..

\section{Kualitas Pelayanan (Service Quality)}

Kualitas pelayanan didasarkan pada penilaian konsumen terhadap pelayanan yang diberikan perusahaan. Kualitas pelayanan harus dimulai dari kebutuhan pelanggan dan berakhir pada persepsi pelanggan. Menurut Ibrahim (2008) kualitas pelayanan adalah sesuatu yang berhubungan dengan terpenuhinya harapan atau kebutuhan pelanggan. Pelayanan dikatakan berkualitas apabila menyediakan produk/jasa sesuai dengan kebutuhan dan harapan pelanggan. Dalam merumuskan strategi dan program pelayanan, perusahaan harus berorientasi kepada kepentingan pelanggan dengan memperhatikan komponen kualitas pelayanan. Ada 5 faktor yang mempengaruhi kualitas pelayanan yaitu: (Moenir, 2002)

a. Faktor kesadaran para pejabat dan petugas yang berkecimpung dalam pelayanan umum.

b. Faktor aturan yang menjadi landasan kerja pelayanan.

c. Faktor organisasi yang merupakan alat serta sistem yang memungkinkan berjalannya mekanismekegiatan pelayanan.

d. Faktor keterampilan petugas.

e. Faktor sarana dan tugas pelayanan.

Perusahaan jasa berupaya memberi kepuasan kepada konsumen bila ingin memenangkan persaingan. Oleh sebab itu, manajer suatu perusahaan harus mendesain dengan meningkatkan kualitas jasanya secara terus menerus. Pelayanan dikatakan berkualitas apabila menyediakan produk/jasa sesuai dengan kebutuhan dan harapan pelanggan. Menurut Parasuraman (2002) indikator kualitas pelayananadalah

1. Bukti Langsung (Tangible) adalah bukti fisik dari suatu jasa yang berupa fasilitas fisik seperti gedung/ruangan, tempat parkir, kebersihan, kerapian dan kenyaman ruangan, kelengkapan peralatan, sarana komunikasi serta penampilan karyawan.

2. Kehandalan (Reliability) yaitu kemampuan perusahaan untuk memberikan pelayanan sesuai dengan apa yang dijanjikan secara akurat dan terpercaya

3. Daya Tanggap (Responsiveness) merupakan suatu kebijakan untuk membantu dan memberikan pelayanan yang cepat (responsive) dan tepat kepada pelanggan

4. Jaminan (Assurance) yaitu meliputi kemampuan karyawan atas pengetahuannya terhadap produk secara tepat, keramah tamahan, keterampilan dalam memberikan informasi, kemampuan dalam memberikan keamanan dalam memanfaatkan jasa yang ditawarkan dan kemampuan dalam menanamkan kepercayaan pelanggan terhadap perusahaan. Oleh karena itu, assurance sangatlah penting karena melibatkan persepsi konsumen terhadap resiko ketidakpastian yang tinggi terhadap kemampuan penyedia jasa.

5. Perhatian (Empathy)

Empati yaitu perhatian dengan memberikan sikap yang tulus dan bersifat individual atau pribadi yang diberikan perusahaan kepada pelangan seperti kemudahan untuk menghubungi perusahaan, kemampuan karyawan untuk berkomunikasi dengan pelanggan dan usaha perusahaan untuk memahami keinginan dan kebutuhan pelanggan.

\section{Loyalitas Nasabah}

Loyalitas merupakan konsep yang tampak mudah dibicarakan dalam konteks sehari-hari, tetapi menjadi lebih sulit ketika dianalisis maknanya. Loyalitas nasabah merupakan pembelian ulang sebuah merek secara konsisten oleh nasabah. Subagyo (2010) Loyalitas nasabah adalah kesetiaan nasabah yang dipresentasikan dalam penggunaan dan pemanfaatan yang konsisten terhadap produk atau jasa sepanjang waktu. Menurut Siswanto (2009) ada beberapa faktor yang mempengaruhi loyalitas nasabah 
yaitu:

1. Tarif

Sejumlah uang yang ditentukan perusahaan sebagai imbalan barang atau jasa yang mereka perdagangkan dan yang diadakan perusahaan untuk memuaskan keinginan nasabah.

2. Pelayanan

Setiap kegiatan atau manfaat yang dapat diberikan suatu pihak kepihak lainnya yang pada dasarnya tidak terwujud dan tidak pula berakibat kepemilikan sesuatu dan produksinya dapat atau tidak dapat dikaaitkan dengan suatu produksi fisik.

3. Promosi

Promosi merupakan kegiatan-kegiatan yang secara aktif dilakukan perusahaan untuk mengidentifikasi dirinya atau memposisikan diri atau produknya.

4. Citra

Persepsi masyarakat terhadap perusahaan atau produknya.

Loyalitas nasabah adalah sikap positif yang kuat terhadap merek atau perusahaan tertentu yang diikuti dengan pola pembelian yang konsisten. Indikator yang berkaitan dengan loyalitas nasabah menurut Sopiah (2013) adalah:

a. Melakukan pembelian secara teratur jasa yang ditawarkan oleh perusahaan (Makes reguler purchase)

b. Nasabah melakukan komunikasi dari mulut ke mulut berkenan dengan produk tersebutterhadap orang lain (Purchase across product and service lines).

c. Merekomendasikan produk lain (Refers other)

Menurut Robinette (2001) indikator dari loyalitas nasabah adalah:

1. Perhatian (Caring), perusahaan harus dapat melihat dan mengatasi segala kebutuhan, harapan, maupun permasalahan yang dihadapi oleh pelanggan.

2. Kepercayaan (Trust), timbul dari suatu proses yang lama sampai kedua belah pihak saling mempercayai.

3. Perlindungan (Length Of Patronage), perusahaan harus dapat memberikan perlindungan kepada pelanggannya, baik berupa kualitas produk, pelayanan, komplain ataupun layanan.

\section{Definisi Operasional}

Adapun variabel yang akan diteliti dalam penelitian ini adalah:

Tabel 2. Definisi Variabel, Indikator, dan Skala Pengukuran

\begin{tabular}{|c|c|c|c|}
\hline Nama Variabel & Definisi Variabel & Indikator & $\begin{array}{c}\text { Skala } \\
\text { Pengukuran }\end{array}$ \\
\hline $\begin{array}{c}\text { Nilai Pelanggan } \\
\left(\mathrm{X}_{1}\right)\end{array}$ & $\begin{array}{l}\text { Nilai } r \text { pelanggan } \\
\text { merupakan keseluruhan } \\
\text { penilaian pelanggan } \\
\text { tentang kegunaan suatu } \\
\text { produk yang berdasar } \\
\text { pada persepsi tentang apa } \\
\text { yang diterima dan apa } \\
\text { yang diberikan. }\end{array}$ & $\begin{array}{l}\text { 1. Nilai Emosional (Emotional } \\
\text { Value) } \\
\text { 2. Nilai Sosial (Social Value) } \\
\text { 3. Nilai Kualitas (Quality Value) } \\
\text { 4. Nilai terhadap Biaya (Price } \\
\text { Value) } \\
\text { 5. Nilai Kinerja (Performance } \\
\text { Value) } \\
\text { 6. Nilai Kredit (Credit Value) } \\
\text { 7. Nilai Pelayanan (Service Value) } \\
\text { 8. Nilai Kenyamanan } \\
\text { (ConvenienceValue) }\end{array}$ & Likert \\
\hline
\end{tabular}




\begin{tabular}{|c|c|c|c|}
\hline Nama Variabel & Definisi Variabel & Indikator & $\begin{array}{c}\text { Skala } \\
\text { Pengukuran }\end{array}$ \\
\hline $\begin{array}{l}\text { Kualitas Pelayanan } \\
\qquad\left(\mathrm{X}_{2}\right)\end{array}$ & $\begin{array}{l}\text { Kualitas } \\
\text { merupakan suatu kondisi } \\
\text { dinamis } \\
\text { berhubungan } \\
\text { produk, jasa, dengan } \\
\text { proses, dan lingkungan } \\
\text { yang memenuhi atau } \\
\text { melebihiharapan. }\end{array}$ & $\begin{array}{l}\text { 1. Bukti langsung (Tangible) } \\
\text { 2. Kehandalan (Reliability) } \\
\text { 3. Daya Tanggap (Responsiveness) } \\
\text { 4. Jaminan (Assurance) } \\
\text { 5. Perhatian (Empathy) } \\
\text { 6. Wujud Fisik } \\
\text { 7. Keyakinan }\end{array}$ & Likert \\
\hline $\begin{array}{l}\text { Loyalitas Nasabah } \\
\text { (Y) }\end{array}$ & $\begin{array}{l}\text { Loyalitas nasabah adalah } \\
\text { sikap positif yang kuat } \\
\text { terhadap merk atau } \\
\text { perusahaan } \\
\text { diikuti tertentu } \\
\text { pembelian yangkonsisten. }\end{array}$ & $\begin{array}{ll}\text { 1. } & \begin{array}{l}\text { Melakukan pembelian secara } \\
\text { teratur yang ditawarkan oleh } \\
\text { perusahaan (Makes reguler } \\
\text { purchase) }\end{array} \\
\text { 2. } & \begin{array}{l}\text { Nasabah melakukan } \\
\text { komuniikasi dari mulut ke } \\
\text { mulut berkenan dengan }\end{array} \\
\text { produk tersebut terhadap } \\
\text { orang lain (Purchase across } \\
\text { product and service lines). } \\
\text { 3. } \begin{array}{l}\text { Merekomendasikan produk } \\
\text { lain }\end{array} \\
\text { (Refers other) } \\
\text { 4. } \begin{array}{l}\text { Perhatian (Caring) } \\
\text { 5. }\end{array} \\
\text { 6epercayaan (Trust) } \\
\text { 6erlindungan (Length of } \\
\text { patronage) }\end{array}$ & Likert \\
\hline
\end{tabular}

Sumber: Diolah Penulis, 2019

\section{Model Analisis}

Model analisis data yang digunakan dalam penelitian ini adalah analisis regresi berganda (multiple regression analysis), yaitu:

$\mathrm{Y}=\mathrm{a}+\mathrm{b}_{1} \mathrm{X}_{1}+\mathrm{b}_{2} \mathrm{X}_{2}+\mathrm{ei}$

Dimana :

$$
\begin{array}{lll}
\mathrm{Y} & =\text { Loyalitas Nasabah } & \mathrm{a} \quad=\text { Konstanta } \\
\mathrm{X}_{1}=\text { Nilai Pelanggan } & \mathrm{b}_{1}, \mathrm{~b}_{2}=\text { Koefisien regresi variabel independen } \\
\mathrm{X}_{2}=\text { Kualitas Pelayanan } & \text { ei } \quad=\text { Standar error }
\end{array}
$$

Analisis regresi berganda digunakan untuk menganalisis pengaruh variabel bebas yang terdiri dari nilai pelanggan $\left(\mathbf{X}_{\mathbf{1}}\right)$ dan kualitas pelayanan $\left(\mathbf{X}_{2}\right)$ terhadap variabel terikat yaitu loyalitas nasabah $(\mathbf{Y})$ baik secara bersama-sama maupun secara parsial. Kemudian dilakukan pembuktian hipotesis dengan tehnik analisis Uji F dan Uji t.

\section{HASIL PENELITIAN DAN PEMBAHASAN}

Hasil regresi berganda pengaruh nilai pelanggan dan kualitas pelayanan terhadap loyalitas nasabah pada Koperasi CU Maju Bersama Kasikan, Tapung Hulu, Kabupaten Kampar, Riau, yaitu: $\mathbf{Y}=$ $9,708+0,223\left(X_{1}\right)+0,119\left(X_{2}\right)+$ ei

Berdasarkan persamaan regresi berganda di atas, nilai pelanggan dan kualitas pelayanan mempunyai hubungan yang positif terhadap loyalitas nasabah. Hubungan positif ini menunjukkan bahwa nilai pelanggan dan kualitas pelayanan berubah searah dengan loyalitas nasabah. 
Tabel 3. Hasil Uji Secara Simultan (Uji F)

\begin{tabular}{|l|r|r|r|r|l|}
\hline \multicolumn{1}{|c|}{ Model $^{\text {Sum of }}$} & \multicolumn{1}{l|}{ SuVA } \\
Squares & Df & Mean Square & F & Sig. \\
\hline $1 \quad$ Regression & 404,780 & 2 & 101,390 & 34,387 &, $000^{\mathrm{b}}$ \\
Residual & 280,580 & 94 & 3,176 & & \\
Total & 684,360 & 96 & & & \\
\hline
\end{tabular}

a. Dependent Variable: Loyalitas Nasabah

b. Predictors: (Constant), Kualitas Pelayanan, Nilai Pelanggan

Sumber: Output SPSS

Berdasarkan hasil output program SPSS, diperoleh nilai F-hitung sebesar 34,387 dengan nilai probabilitas (signifikansi) sebesar $0,000<0,05$. Dengan demikian $\mathrm{H}_{0}$ ditolak dan $\mathrm{H}_{1}$ diterima,. Artinya terdapat pengaruh signifikan nilai pelanggan dan kualitas pelayanan terhadap loyalitas nasabah pada KSP (CU ) Maju Bersama Kasikan, Tapung Hulu, KabupatenKampar, Riau.

\section{Uji Parsial (Uji t)}

\section{Coefficients $^{\mathrm{a}}$}

Tabel 4. Uji Parsial (Uji t)

\begin{tabular}{|c|c|c|c|c|c|}
\hline \multirow[b]{2}{*}{ Model } & \multicolumn{2}{|c|}{$\begin{array}{c}\text { Unstandardized } \\
\text { Coefficients }\end{array}$} & \multirow{2}{*}{\begin{tabular}{|c}
$\begin{array}{l}\text { Standardized } \\
\text { Coefficients }\end{array}$ \\
Beta
\end{tabular}} & \multirow[b]{2}{*}{$\mathrm{T}$} & \multirow[b]{2}{*}{ Sig. } \\
\hline & $\mathrm{B}$ & Std. Error & & & \\
\hline (Constant) & 9,708 & 3,835 & & 3,461 & , 183 \\
\hline Nilai Pelanggan & ,223 & 059 &, 246 & 2,394 & ,010 \\
\hline Kualitas Pelayanan & ,119 & ,065 & ,221 & 2,288 & ,000 \\
\hline
\end{tabular}

a. Dependent Variable: Loyalitas Nasabah

Sumber : Output SPSS

Berdasarkan hasil uji parsial pada tabel $4 \mathrm{di}$ atas untuk variabel nilai pelanggan diperolehkoefisien regresi dengan arah positif sebesar 0,223 dengan nilai signifikansi sebesar 0.010 dimana 0.010 $<0.05$ sehingga $\mathrm{H}_{1}$ diterima dan $\mathrm{H}_{0}$ ditolak. Artinya nilai pelanggan berpengaruh positif dan signifikan secara parsial terhadap loyalitas nasabah.

Koefisien regresi variabel kualitas pelayanan diperoleh dengan arah positif sebesar 0,119 dengan nilai signiifikansi sebesar 0,000 dimana $0,000<0,05$ sehingga $\mathrm{H}_{1}$ diterima dan Ho ditolak. Artinya kualitas pelayanan berpengaruh positif dan signifikan secara parsial terhadap loyalitas nasabah.

\section{Nilai Koefisien Determinasi (R Square)}

Tabel 5. Nilai Koefisien Determinasi (R Square)

\section{Model Summary}

\begin{tabular}{|c|c|c|c|c|}
\hline Model & $\mathrm{R}$ & $\mathrm{R}$ Square & Adjusted R Square & Std. Error of the Estimate \\
\hline 1 &, $858^{\mathrm{a}}$ &, 782 &, 653 & 1,485 \\
\hline
\end{tabular}

a. Predictors: (Constant), TX2, TX1

Sumber: Output SPSS

Koefisien determinasi (R Square) sebesar 0,782 atau 78,2\% berarti variasi loyalitas nasabah dapat dijelaskan oleh variasi nilai pelanggan dan kualitas pelayanan sebesar 78,2\% dan sisanya sebesar 0,218 atau $21,8 \%$ dapat dijelaskan oleh faktor lain yang tidak diteliti dalam penelitian ini.

\section{KESIMPULAN DAN SARAN}

\section{Kesimpulan}

1. Persamaan regresi linear berganda: $Y=9,708+0,223\left(X_{1}\right)+0,119\left(X_{2}\right)+$ ei

Dilihat dari persamaan regresi linier berganda di atas dapat disimpulkan bahwa nilai pelanggan dan kualitas pelayanan berpengaruh positif terhadap loyalitas nasabah pada KSP (CU) Maju 
Bersama Kasikan, Tapung Hulu, Kabupaten Kampar, Riau. Variabel yang paling berpengaruh terhadap loyalitas nasabah adalah nilai pelanggan $\left(\mathrm{X}_{1}\right)$, karena nilai koefisien korelasinya lebih besar daripada nilai kualitas pelayanan $\left(\mathrm{X}_{2}\right)$.

2. Dilihat dari hasil uji $F$, disimpulkan bahwa nilai pelanggan $\left(X_{1}\right)$ dan kualitas pelayanan $\left(X_{2}\right)$ berpengaruh positif dan signifikan secara simultan terhadap loyalitas nasabah (Y) pada KSP (CU) Maju Bersama Kasikan, Tapung Hulu, Kabupaten Kampar, Riau. Hal ini dapat dilihat dari tingkat signifikansi $0,000<0,05$ sehingga $\mathrm{H}_{0}$ ditolak dan $\mathrm{H}_{1}$ diterima.

3. Dilihat dari hasil uji t, disimpulkan bahwa nilai pelanggan $\left(X_{1}\right)$ dan kualitas pelayanan $\left(X_{2}\right)$ berpengaruh positif dan signifikan secara parsial terhadap loyalitas nasabah (Y) pada KSP (CU) Maju Bersama Kasikan, Tapung Hulu, Kabupaten Kampar, Riau, sehingga $\mathrm{H}_{1}$ diterima dan $\mathrm{H}_{0}$ ditolak.

4. Nilai koefisien determinasi (R Square) sebesar 0,782. Artinya, loyalitas nasabah dapat dijelaskan oleh nilai pelanggan dan kualitas pelayanan sebesar 78,2\%, sedangkan 21,8\% lagi dijelaskan oleh faktor lain yang tidak termasuk dalam variabel penelitian.

\section{Saran}

1. Kualitas pelayanan kepada nasabah ditingkatkan sehingga keinginan nasabah untuk bertransaksi lebih cepat dapat terpenuhi.

2. Pimpinan perusahaan sebaiknya meningkatkan nilai pelanggan yang selama ini telah dirasakan cukup baik.

\section{DAFTAR PUSTAKA}

Abdurrahman, N. H, 2015. Manajemen Strategi Pemasaran. CV Pustaka Setia. Bandung Arikunto. 2006. Prosedur Penelitian Suatu Pendekatan Praktek..PT. Rineka Cipta. Jakarta :Buchari Alma. 2007, Manajemen Pemasaran dan Pemasaran Jasa. CV. Alfabeta. Bandung Daryanto. 2011. Manajemen Pemasaran. PT Sarana Tutorial Nurani Sejahtera. Bandung.

Fandi Tjiptono, 2002, Manajemen Jasa, Penerbit Andi. Yogyakarta.

Ghozali, Iman. 2005. Aplikasi Analisis Multivariate Dengan SPSS. Badan Penerbit UNDIP. Semarang.

Hair , Carl, Mc.Daniel, 2001, Pemasaran. Edisi Pertama, Salemban Empat, Jakarta

Hurriyati, Ratih 2005, Bauran Pemasaran dan Loyalitas Konsumen. Alfabeta. Bandung

Husein Umar, 2003, Metode Penelitian Untuk Skripsi dan Tesis Bisnis. PT. Gramedia Pertama.Jakarta.

Ibrahim, Amin. 2008. Teori Konsep Pelayanan Publik Serta Implementasinya..Mandar Maju. Bandung.

Jogiyanto H. M. 2004. Analisis dan Desain Sistem Informasi, Edisi Kedua, Yogyakarta

Kotler, Philip dan Gary Armstrong, 2012, Prinsip-Prinsip Pemasaran, Jilid 1,Edisi Kedelapan, Erlangga.Jakarta

Lovelock. Christoper. 2005. Manajemen Pemasaran Jasa, Kelompok Gramedia Indeks, Indonesia.

Lupiyoadi, Rambat. 2001. Manajemen Pemasaran Jasa, Teori dan Praktek. Edisi Pertama. Salemba Empat. Jakarta..

Lupiyoadi dan Hamdani, 2006. Manajemen Pemasaran Jasa Edisi Kedua. Penerbit Salemba Empat.Jakarta

Moenir, H,A,S, 2002, Manajemen Pelayanan Umum di Indonesia, Bumi Aksara. Jakarta.

Sangadji, Etta Mamang \& Sopiah. 2013. Perilaku Konsumen-Pendekatan Praktis Disertai Himpunan Jurnal Penelitian. Andi. Yogyakarta.

Siswanto, H. B 2009, Pengantar Manajemen, Bumi Aksara, Jakarta.

Subagyo, Ahmad. 2010. Marketing In Business, Edisi Pertama, Cetakan Pertama, Penerbit : Mitra Wacana Media., Jakarta.

Swastha, Basu dan Irawan, 2003, Manajemen Pemasaran Modern. Penerbit: Liberty. Yogyakarta.

Sheth. Jagdish, \& Mittal Banwari. 2004. Comsumer Behavior: A Manajerial Perspective, Edisi Kedua. Thompson South Western. USA.

Sugiyono, 2012, Metode Penelitian Kuantitatif, Kualitatif dan R \& D. Alfabeta. Bandung. 
Sujarweni, V, Wiratna. 2015. Metodologi Penelitian Bisnis \& Ekonomi. Pustaka Baru Press. Yogyakarta

Yazid. 2008. Pemasaran Jasa : Konsep dan Implementasi. Ekonosia. Yogyakarta Zeithaml, Valarie A and Bitner, MJ. 2003. Service Marketing. Tata McGraw-Hill.

\section{JURNAL}

Irawan, Richi. 2017 Pengaruh Kualitas Layanan dan Nilai Nasabah terhadap Loyalitas Nasabah Bank BRI KK Unisma Malang. Jurnal Ilmiah Riset Manajemen. Vol. 06 No 3 Agustus 2017.

Nanang Tasunar. 2006. Kualitas Pelayanan sebagai Strategi Menciptakan Kepuasan pada Pangkalan Pendaratan Ikan (PPI) Morodemak, Jurnal Sains Pemasaran Indonesia, Vol. V, No 1 Mei 2006, h.41-62 